\title{
Analisis Faktor-Faktor yang Mempengaruhi Kepatuhan Wajib Pajak (Studi Kasus pada Wajib Pajak Orang Pribadi dan Badan di Wilayah Kota Jambi)
}

\author{
${ }^{1}$ Wirmie Eka Putra, ${ }^{2}$ Indra Lila Kusuma, ${ }^{3}$ Maya Widyana Dewi \\ ${ }^{1}$ Fakultas Ekonomi dan Bisnis Universitas Jambi, Indonesia \\ ${ }^{2,3}$ Sekolah Tinggi Ilmu Ekonomi AAS Surakarta, Indonesia \\ ${ }^{1}$ Email korenpondensi: wirmie_eka@unja.ac.id
}

\begin{abstract}
This study aims to examine the effect of tax amnesty, knowledge of taxation, tax services and tax sanctions on taxpayer compliance. The sampling technique that will be used in this study is purposive sampling technique. Primary data is collected by distributing questionnaires. The research sample was 45 respondents of individual and body taxpayers found in Jambi City Region. Data analysis techniques in this study are descriptive statistics and multiple regression analysis. The software used for data processing is SPSS version 21 for Windows. The results of testing the hypothesis are as follows. Simultaneously, tax amnesty, knowledge of taxation, tax authorities and tax sanctions affect taxpayer compliance. Partially, tax amnesty, knowledge of taxation on taxation sanctions has an effect on taxpayer compliance and service of tax authorities has no effect.
\end{abstract}

Keywords: Tax Amnesty, Knowledge of Taxation, Fiscal Services, Tax Sanctions, Compliance with Taxpayers

Saran sitasi: Putra, W., Kusuma, I., \& Dewi, M. (2019). Analisis Faktor-Faktor yang Mempengaruhi Kepatuhan Wajib Pajak (Studi Kasus pada Wajib Pajak Orang Pribadi dan Badan di Wilayah Kota Jambi). Jurnal Akuntansi dan Pajak, 20(1), 43-54. doi: http://dx.doi.org/10.29040/jap.v20i1.360

DOI: http://dx.doi.org/10.29040/jap.v20i1.360

\section{Pendahuluan}

Suatu negara dapat melaksanakan pembangunan nasional apabila terdapat dana yang tersedia untuk membiayai pembangunan tersebut. Sumber dana atau sumber penerimaan suatu negara pada dasarnya dapat dibedakan menjadi penerimaan yang bersumber dari sektor internal dan eksternal. Salah satu sumber penerimaan negara yang berasal dari sektor internal adalah pajak. Menurut Undang-Undang Nomor 16 Tahun 2009 tentang perubahan keempat atas Undang-Undang Nomor 6 Tahun 1983 Tentang Ketentuan Umum dan Tata Cara Perpajakan pada Pasal 1 Angka 1, pajak adalah kontribusi wajib kepada negara yang terutang oleh orang pribadi atau badan yang bersifat memaksa berdasarkan Undang-Undang dengan tidak mendapatkan imbalan secara langsung dan digunakan untuk keperluan negara bagi sebesarbesarnya kemakmuran rakyat. Pajak memiliki peranan yang sangat penting sebagai sumber utama penerimaan negara, oleh karena itu pelaksanaan perpajakan sangat diatur guna mempertahankan penerimaan negara (Lianty, Hapsari, et al, 2017).

Pajak merupakan sumber penerimaan negara terbesar sehingga berbagai cara untuk mensukseskan pendapatan dari sektor pajak dilakukan oleh pemerintah. Inovasi yang telah dilakukan oleh pemerintah diantaranya dengan 
program sunset policy dan tax amnesty (Suyanto, et al, 2016).

Pajak merupakan iuran yang dibayarkan oleh rakyat kepada negara yang masuk dalam kas negara yang melaksanaannya mengacu pada undang - undang serta pelaksanaannya dapat dipaksakan tanpa adanya balas jasa. Iuran tersebut digunakan oleh negara untuk melakukan pembayaran atas kepentingan umum (Mardiasmo, 2009).

(Widyaningsih, 2011) mendefinisikan pajak sebagai iuran rakyat kepada kas negara berdasarkan Undang-Undang No 6 tahun 1983 sehingga dapat dipaksakan dengan tiada mendapat balas jasa secara langsung.

Indonesia pernah menyelenggarakan tax amnesty yakni tahun 1964 melalui Penetapan Presiden No. 5 tahun 1964 dan tahun 1984 melalui Keputusan Presiden (Kepres) No. 26 tahun 1984 Tentang Pengampunan Pajak dan Kepres No. 72 tahun 1984 tentang Perubahan Keputusan Presiden Nomor 26 Tahun 1984 Tentang Pengampunan Pajak. Sarana prasarana yang kurang mendukung serta perumusan tujuan yang tidak jelas menyebabkan dua tax amnesty ini tidak berhasil (Bagiada \& Darmayasa, 2016).

Pemerintah telah mengerahkan serangkaian upaya meningkatkan kepatuhan pajak melalui reformasi perpajakan (tax reform) pertama yang dimulai sejak tahun 1984 (Fidiana, 2016).

Kepatuhan wajib pajak (WP) merupakan pemenuhan kewajiban perpajakan yang dilakukan oleh pembayar pajak dalam rangka memberikan kontribusi bagi pembangunan negara yang diharapkan didalam pemenuhannya dilakukan secara sukarela (Mandagi, et al, 2014). Sedangkan menurut (Winerungan, 2013) mendefinisikan kepatuhan pajak sebagai suatu keadaan dimana wajib pajak memenuhi semua kewajiban perpajakan dan melaksanakan hak perpajakannya, maka konteks kepatuhan dalam penelitian ini mengandung arti bahwa Wajib Pajak berusaha untuk mematuhi peraturan hukum perpajakan yang berlaku, baik memenuhi kewajiban ataupun melaksanakan hak perpajakannya.
Kepatuhan yang dikemukakan oleh (Rahayu, 2010) sebagai suatu iklim kepatuhan dan kesadaran pemenuhan kewajiban perpajakan yang tercermin dalam situasi a) wajib pajak paham atau berusaha untuk memahami semua ketentuan peraturan perundang-undangan; b) Mengisi formulir pajak dengan lengkap dan jelas; c) Menghitung jumlah pajak yang terutang dengan benar; d) Membayar pajak yang terutang tepat pada waktunya.

Pengampunan pajak bertujuan untuk memberikan tambahan penerimaan pajak dan kesempatan bagi wajib pajak yang tidak patuh menjadi wajib pajak patuh (Devano \& Rahayu, 2006).

Tax amnesty merupakan kebijakan pemerintah di bidang perpajakan yang memberikan penghapusan pajak yang seharusnya terutang dengan membayar tebusan dalam jumlah tertentu (Sari \& Fidiana, 2017). Menurut PMK No. 118/PMK.03/2016 tax amnesty adalah adalah penghapusan pajak yang seharusnya terutang, tidak dikenai sanksi administrasi perpajakan dan sanksi pidana di bidang perpajakan, dengan cara mengungkap harta dan membayar uang Tebusan sebagaimana diatur dalam Undang-Undang Pengampunan Pajak.

Tax amnesty dipandang sebagai jalan keluar untuk meningkatkan penerimaan di masa yang akan datang karena tax amnesty memberikan kesempatan kepada wajib pajak untuk masuk atau kembali ke administrasi perpajakan. Pada umumnya pemberian tax amnesty bertujuan untuk meningkatkan penerimaan pajak dalam jangka pendek, meningkatkan kepatuhan pajak di masa yang akan datang, mendorong repatriasi modal atau aset dan transisi ke sistem perpajakan yang baru (Darussalam, 2014). Secara psikologis implementasi tax amnesty tidak baik/tidak memihak pada WP yang selama ini sudah taat membayar pajak. Pelaksanaan tax amnesty berdampak tidak baik apabila sering di lakukan, karena wajib pajak yang selama ini sudah taat akan malas membayar pajak sebab kedepan akan ada tax amnesty (Ragimun, 2015). 
Sementara penerapan tax amnesty jika ditinjau dari perspektif teori etika deontologi telah berjalan dengan baik dengan diikuti oleh wajib pajak sebagai suatu kewajiban tanpa melihat hasil akhir baik dan buruknya bagi diri wajib pajak tersebut. Hal ini dibuktikan dengan berhasilnya penerapan tax amnesty berupa peningkatan penerimaan pajak dengan total harta yang dilaporkan terdiri dari deklarasi harta luar negeri Rp. 3.676 trilyun dan deklarasi harta luar negeri mencapai Rp. 1.031 trilyun. Sementara penarikan dana dari luar negeri (reptriasi) mencapai Rp.147 trilyun (Kusuma, 2018).

Menurut (Rahayu, 2010) konsep pengetahuan pajak ada 3, a) Pengetahuan mengenai Ketentuan Umum dan Tata Cara Perpajakan (KUP), yaitu pengetahuan mengenai kewajiban dan hak WP, SPT, NPWP, dan Prosedur Pembayaran, Pemungutan, serta Pelaporan Pajak; b) Pengetahuan mengenai sistem perpajakan di Indonesia, sistem perpajakan yang diterapkan di Indonesia saat ini yaitu self assesment system; c) Pengetahuan mengenai fungsi perpajakan, yaitu mengetahui bahwa fungsi pajak adalah sebagai sumber penerimaan negara dan sebagai alat untuk mengatur kebijakan di bidang sosial dan ekonomi.

Pengetahuan dan pemahaman pertaturan perpajakan yang dimaksud mengerti dan paham tentang KUP yang meliputi tentang bagaimana cara menyampaikan Surat Pemberitahuan (SPT), pembayaran, tempat pembayaran, denda dan batas waktu pembayaran atau pelaporan SPT (Resmi, 2009).

Menurut (Siregar et al, 2012) pelayanan fiskus adalah pemberian layanan (melayani) keperluan orang atau masyarakat yang mempunyai kepentingan pada organisasi itu sesuai dengan aturan pokok dan tata cara yang telah ditetapkan.

Menurut Undang-Undang KUP Nomor 28 Tahun 2007 yang sudah dijelaskan yaitu salah satunya mengenai sanksi pajak, wajib pajak dapat dikenakan sanksi denda yang berupa administrasi, bunga, dan sanksi pidana. Sanksi pajak merupakan jaminan bahwa ketentuan peraturan perundang-undangan perpajakan (norma perpajakan) akan dituruti/ ditaati/ dipatuhi, dengan kata lain sanksi perpajakan merupakan alat pencegah agar wajib pajak tidak melanggar norma perpajakan. (Mardiasmo, 2011) mengemukakan bahwa sanksi perpajakan merupakan jaminan bahwa ketentuan peraturan perundang-undangan perpajakan (norma perpajakan) akan dituruti, ditaati, dan dipatuhi.

Penelitian yang dilakukan (Sari \& Fidiana, 2017) menunjukkan bahwa tax amnesty memiliki pengaruh positif terhadap kepatuhan wajib pajak. (Alfiyah \& Latifah, 2017) melakukan penelitian dengan hasil tax amnesty berpengaruh signifikan terhadap kepatuhan wajib pajak orang pribadi. Penelitian yang dilakukan oleh (Sari \& Fidiana, 2017) bahwa pengetahuan perpajakan memiliki pengaruh positif terhadap kepatuhan wajib pajak. Sejalan dengan penelitian (Lianty et al., 2017) bahwa pengetahuan perpajakan berpengaruh signifikan terhadap kepatuhan wajib pajak orang pribadi di KPP Pratama Bandung Bojonagara. (Mahfud et al, 2017) melakukan penelitian dengan hasil pemahaman peraturan perpajakan berpengaruh terhadap kepatuhan wajib pajak.

Penelitian yang dilakukan oleh (Lianty et al., 2017) bahwa pelayanan fiskus berpengaruh signifikan terhadap kepatuhan wajib pajak orang pribadi di KPP Pratama Bandung Bojonagara. Sejalan dengan penelitian (Mahfud et al., 2017) menyatakan bahwa pelayanan fiskus secara simultan berpengaruh terhadap kepatuhan wajib pajak. Sedangkan Penelitian yang dilakukan oleh (Sari \& Fidiana, 2017) menyatakan bahwa pelayanan fiskus tidak berpengaruh terhadap kepatuhan wajib pajak. Sejalan dengan penelitian (Winerungan, 2013) yang menyatakan pelayanan fiskus tidak berpengaruh terhadap kepatuhan wajib pajak orang pribadi di KPP Pratama Manado.

Penelitian yang dilakukan oleh (Alfiyah \& Latifah, 2017) menyatakan bahwa sanksi pajak berpengaruh positif signifikan terhadap kepatuhan wajib pajak. Sedangkan Penelitian (Winerungan, 2013) menyatakan bahwa Sanksi perpajakan tidak berpengaruh terhadap kepatuhan wajib pajak orang pribadi. 
Alasan penelitian mereplikasi penelitian ini karena adanya inkonsistensi hasil dalam beberapa penelitian terdahulu. Banyak penelitian yang memberikan kesimpulan berbeda dengan penelitian lain. Penelitian yang dilakukan oleh (Sari \& Fidiana, 2017) bahwa tax amnesty memiliki pengaruh positif terhadap kepatuhan wajib pajak. Sedangkan penelitian yang dilakukan oleh (Alfiyah \& Latifah, 2017) menyatakan bahwa tax amnesty berpengaruh positif signifikan terhadap kepatuhan wajib pajak.

Penelitian yang dilakukan oleh (Sari \& Fidiana, 2017) menyatakan bahwa pengetahuan perpajakan memiliki pengaruh positif terhadap kepatuhan wajib pajak. Penelitian yang dilakukan oleh (Lianty et al., 2017) menyatakan bahwa pengetahuan perpajakan berpengaruh signifikan terhadap kepatuhan wajib pajak orang pribadi.

Penelitian yang dilakukan oleh (Lianty et al., 2017) menyatakan bahwa pelayanan fiskus berpengaruh signifikan terhadap kepatuhan wajib pajak orang pribadi. Sejalan dengan penelitian (Murti et al, 2014) menyatakan pelayanan fiskus berpengaruh terhadap kepatuhan wajib pajak orang pribadi. Sedangkan penelitian (Sari \& Fidiana, 2017) menyatakan bahwa pelayanan fiskus tidak memiliki pengaruh terhadap kepatuhan wajib pajak.

Penelitian yang dilakukan oleh (Alfiyah \& Latifah, 2017) menyatakan bahwa sanksi pajak berpengaruh positif signifikan terhadap kepatuhan wajib pajak. Sedangkan penelitian (Winerungan, 2013) menyatakan bahwa sanksi perpajakan tidak berpengaruh terhadap kepatuhan wajib pajak orang pribadi di KPP Pratama Manado.

Fenomena yang terkait dengan variabel dalam penelitian ini adalah pelayanan fiskus pada $e$-filling Online pajak yang terjadi yaitu jika diwaktu-waktu terakhir penggunaan terjadi gangguan, sering terjadi penolakan oleh sistem jika tidak sesuai tanpa ada penjelasan dan setiap pembetulan tidak dapat dilakukan secara online.
Kepatuhan wajib pajak dalam memenuhi kewajibannya membayar pajak tergantung pada bagaimana petugas pajak memberikan mutu pelayanan yang terbaik kepada wajib pajak. Fiskus diharapkan memiliki kompetensi keahlian, pengetahuan, dan pengalaman, dalam hal kebijakan perpajakan, administrasi pajak dan perundang-undangan perpajakan.

Berdasarkan fenomena yang terjadi yaitu jika masih terdapat harta yang belum sepenuhnya diungkap pada saat melakukan amnesty pajak yang lalu, wajib pajak dikenakan sanksi pasal 18 UU amnesty pajak yaitu denda sebesar 200\% (Independen, 2018). Tempat Penelitian pada wajib pajak orang pribadi dan badan di wilayah Kota Jambi dengan periode yang lebih up to date yaitu 2018.

Alasan peneliti memilih objek pada wajib pajak orang pribadi dan badan di wilayah Kota Jambi karena adanya berbagai fenomena yang terjadi yang membuat menarik untuk diteliti oleh peneliti yaitu adanya ketidakstabilan persentase kepatuhan wajib pajak di Kota Jambi tahun 2012 sebesar 74,80\%, 2013 sebesar 73\%, 2014 sebesar $73 \%$ dan 2015 sebesar 79,88\%. Alasan lainnya peneliti ingin melihat apakah ada pengaruh dari tax amnesty, pengetahuan perpajakan, pelayanan fiskus dan sanksi perpajakan terhadap kepatuhan wajib pajak.

Berdasarkan uraian diatas maka pokok permasalahan dalam penelitian ini adalah: apakah tax amnesty, pengetahuan perpajakan, pelayanan fiskus dan sanksi perpajakan berpengaruh secara simultan terhadap kepatuhan wajib pajak? apakah tax amnesty berpengaruh secara parsial terhadap kepatuhan wajib pajak? apakah pengetahuan perpajakan berpengaruh secara parsial terhadap kepatuhan wajib pajak? apakah pelayanan fiskus berpengaruh secara parsial terhadap kepatuhan wajib pajak? apakah sanksi perpajakan berpengaruh secara parsial terhadap kepatuhan wajib pajak? berapa besar pengaruh tax amnesty, pengetahuan perpajakan, pelayanan fiskus dan sanksi perpajakan terhadap kepatuhan wajib pajak?. 
Adapun tujuan yang ingin dicapai dalam penelitian ini adalah untuk menganalisis secara empiris pengaruh tax amnesty, pengetahuan perpajakan, pelayanan fiskus dan sanksi perpajakan secara simultan terhadap kepatuhan wajib pajak. untuk menganalisis secara empiris pengaruh tax amnesty secara parsial terhadap kepatuhan wajib pajak, untuk menganalisis secara empiris pengaruh pengetahuan perpajakan secara parsial terhadap kepatuhan wajib pajak. untuk menganalisis secara empiris pengaruh pelayanan fiskus secara parsial terhadap kepatuhan wajib pajak. untuk menganalisis secara empiris pengaruh sanksi perpajakan secara parsial terhadap kepatuhan wajib pajak. untuk mengetahui seberapa besar pengaruh tax amnesty, pengetahuan perpajakan, pelayanan fiskus dan sanksi perpajakan terhadap kepatuhan wajib pajak.

Menurut (Pramushinta \& Siregar, 2011) selain menghasilkan peningkatan penerimaan pajak tax amnesty juga diharapkan mampu meningkatkan kepatuhan serta efektivitas pembayaran karena daftar kekayaan wajib pajak semakin akurat setelah mengikuti amnesti. Wajib pajak yang sebelumnya tidak patuh dengan mengikuti program tax amnesty akan menjadi wajib pajak yang patuh. Pengetahuan perpajakan berperan penting dalam meningkatkan kepatuhan wajib pajak dapat diartikan apabila wajib pajak telah mengetahui seluruh ketentuan perpajakan yang berlaku maka wajib pajak akan dengan mudah melaksanakan kewajiban perpajaknnya (Zuhdi et al, 2015). Sanksi pajak menjadi salah satu faktor dalam meningkatkan kepatuhan wajib pajak. Berdasarkan teori atribusi, sanksi perpajakan merupakan penyebab eksternal yang mempengaruhi persepsi wajib pajak dalam penilaian mengenai perilaku kepatuhan wajib pajak untuk melaksanakan kewajiban perpajakan.

H1: Tax amnesty, pengetahuan perpajakan, pelayanan fiskus dan sanksi perpajakan berpengaruh secara simultan terhadap kepatuhan wajib pajak.
Berdasarkan teori atribusi, tax amnesty merupakan penyebab eksternal yang mempengaruhi persepsi wajib pajak untuk berperilaku patuh dalam melaksanakan kewajiban perpajakan. Berdasarkan teori pembelajaran sosial, wajib pajak dapat belajar melalui pengamatan dan pengalaman langsung mengenai dampak diberlakukannya program tax amnesty, untuk mengetahui apa fungsi serta keuntungan bila mengikuti program tersebut. Keberadaan tax amnesty merupakan kesempatan terbatas yang diberikan Pemerintah kepada organisasi atau individu untuk meningkatkan ketaatan terhadap peraturan pajak (Alfiyah \& Latifah, 2017).

Wajib pajak yang sebelumnya tidak patuh dengan mengikuti program tax amnesty akan menjadi wajib pajak yang patuh. Dan untuk membangun kepatuhan wajib pajak sukarela, setelah tax amnesty sebaiknya dilakukan transparansi atas penggunaan uang pajak serta alokasinya yang harus tepat sasaran dan berkeadilan (Ngadiman \& Huslin, 2015).

H2: Tax Amnesty berpengaruh secara parsial terhadap kepatuhan wajib pajak.

Pengetahuan perpajakan berperan penting dalam meningkatkan kepatuhan WP dapat diartikan apabila WP telah mengetahui seluruh ketentuan perpajakan yang berlaku maka wajib pajak akan dengan mudah melaksanakan

kewajiban perpajaknnya (Zuhdi et al., 2015). Sehingga seiring dengan meningkatnya pengetahuan perpajakan yang dimiliki wajib pajak dapat mempengaruhi patuh tidaknya wajib pajak karena wajib pajak sudah mengetahui atas konsekuensi maupun sanksi yang yang bisa dikenakan jika mereka tidak melaksanakan kewajibannya dengan benar.

H3: Pengetahuan perpajakan berpengaruh secara parsial terhadap kepatuhan wajib pajak.

Menurut (Siregar et al., 2012) pelayanan fiskus adalah pemberian layanan (melayani) keperluan orang atau masyarakat yang mempunyai kepentingan pada organisasi itu sesuai dengan aturan pokok dan tata cara yang telah ditetapkan. Semakin baik pelayanan yang 
diberikan oleh fiskus kepada wajib pajak akan mendorong wajib pajak untuk melaksanakan kewajiban perpajakannya sehingga kepatuhan wajib pajak dapat tercipta.

H4: Pelayanan fiskus berpengaruh secara parsial terhadap kepatuhan wajib pajak

Berdasarkan teori atribusi, sanksi perpajakan merupakan penyebab eksternal yang mempengaruhi persepsi wajib pajak dalam penilaian mengenai perilaku kepatuhan wajib pajak untuk melaksanakan kewajiban perpajakan. Berdasarkan teori pembelajaran sosial, wajib pajak dapat belajar melalui pengamatan dan pengalaman langsungnya melalui pemberian sanksi yang dikenakan aparat pajak kepada wajib pajak yang melanggar norma perpajakan. Sanksi pajak dibuat adalah untuk mendukung agar wajib pajak mematuhi peraturan perpajakan.

H5: Sanksi Perpajakan berpengaruh secara parsial terhadap Kepatuhan Wajib Pajak.

Karakteristik penting pelaporan keuangan yaitu Ketepatan Penyampaian waktu pelaporan keuangan (timeliness). Laporan keuangan yang diberikan tepat waktu mengurangi resiko yang ketidaksesuaian didalam penafsiran informasi laporan keuangan. Laporan keuangan public sebagai sinyal perusahaan menunjukan informasi dalam kebutuhan pembuatan keputusan investor (McGee, 2007); ( McGee \& Yuan, 2008). Relevansi informasi dikomunikasikan hilang jika terlambat disampaikan. Apabila informasi tidak disampaian diluar jangka yang ditetapkan menyebabkan nilai informasi berkurang dalam mengambil suatu keputusan untuk penentuan tindakan masa akan datang (Raesya, 2010).

\section{Metode Penelitian}

Pengumpulan data sebagai prosedur yang sistematik dan standar untuk memperoleh data yang diperlukan (Arikunto, 2009). Pengumpulan data dilakukan dengan menggunakan kuesioner, yaitu sejumlah daftar pertanyaan yang diajukan kepada responden. Penelitian ini menggunakan jenis data subjek dalam penelitian ini. Data subjek adalah jenis data penelitian yang berupa opini, sikap, pengalaman, atau karakteristik seseorang atau kelompok orang yang menjadi subjek penelitian (responden). Data subjek merupakan data penelitian yang dilaporkan sendiri oleh responden secara individual atau secara kelompok. Penelitian ini menggunakan data primer. Data primer adalah data yang diperoleh dari tangan pertama untuk analisis berikutnya untuk menemukan solusi atau masalah yang diteliti (Sekaran, 2006).

Menurut (Sekaran, 2006) populasi mengacu kepada keseluruhan kelompok, orang, kejadian, atau hal yang ingin peneliti investigasi. Populasi yang diteliti adalah 5.166 WPOP dan 943 Wajib Pajak Badan yang terdaftar di KPP Pratama Jambi. Teknik penentuan sampel yang akan digunakan dalam penelitian ini adalah teknik purposive sampling. Ada dua jenis metode dalam pemilihan sampel purposive sampling yaitu pemilihan sampel berdasarkan pertimbangan dan berdasarkan kuota. Sampel pada penelitian ini yang digunakan berjumlah 45 WPOP dan Badan yang ditemui di Wilayah Kota Jambi.

Metode analisis data yang digunakan dalam penelitian adalah analisis regresi berganda dengan bantuan komputer melalui program SPSS 22.0 for Windows. Analisis regresi berganda merupakan teknik statistik melalui koefisien parameter untuk mengetahui besarnya pengaruh variabel independen terhadap variabel dependen. Pengujian hipotesis baik secara parsial maupun secara bersama-sama, dilakukan setelah model regresi yang digunakan bebas dari uji asumsi klasik. Tujuannya adalah agar hasil penelitian tepat dan efisien. Persamaan regresi yang digunakan adalah sebagai berikut (Ghozali \& Chariri, 2016):

$$
\mathrm{Y}=\alpha+\beta 1 X 1+\beta 2 X 2+\beta 3 X 3+\beta 4 X 4+e
$$

Keterangan:

$\mathrm{Y}=$ Kepatuhan Wajib Pajak

$\alpha=$ Konstanta

$\mathrm{X}_{1}=$ Tax Amnesty

$\mathrm{X}_{2}=$ Pengetahuan Perpajakan

$\mathrm{X}_{3}=$ Pelayanan Fiskus

$\mathrm{X}_{4}=$ Sanksi Perpajakan

$\beta_{1}, \beta_{2}, \beta_{3}, \beta_{4}=$ Koefisien Regresi

$\mathrm{e}=$ Error Term 


\section{Hasil dan Pembahasan}

\subsection{Hasil Penelitian}

Responden yang digunakan dalam penelitian ini adalah wajib pajak Orang Pribadi dan Badan yang berada di wilayah Kota Jambi. Pengumpulan data dalam penelitian ini dilakukan dengan menyebarkan kuesioner kepada responden yaitu 27 wajib pajak orang pribadi dan 18 wajib pajak orang badan pada Wilayah Kota Jambi. Proses pendistribusian hingga pengumpulan data dilakukan selama 1 bulan yaitu mulai tanggal 27 September 2018 sampai dengan 7 November 2018. Kuesioner yang disebar sejumlah 45 kuesioner, kuesioner yang dapat diolah yaitu sejumlah 45 kuesioner dengan jumlah pertanyaan 26 item.

Tabel 1 menunjukan bahwa responden yang berjenis kelamin laki-laki berjumah 27 orang dan responden yang berjenis kelamin perempuan 18 orang. Kemudian bila ditinjau berdasarkan pendidikan terakhir maka data menunjukkan sebanyak 1 orang berpendidikan terakhir diploma, 22 orang pendidikan terakhir S1, 22 orang pendidikan terakhir lainnya.

Apabila ditinjau berdasarkan umur responden, maka dapat diketahui bahwa rentang usia resonden peneliti sebanyak 12 orang berusia 25-35 tahun, sebanyak 15 orang berusia 36-45 tahun, 46-55 tahun sebanyak 17 orang, dan 1 orang sebanyak >56 tahun. Kemudian bila ditinjau berdasarkan penghasilan maka data menunjukkan sebanyak 16 orang memiliki penghasilan Rp.0-Rp.50.000.000, sebanyak 15 orang memiliki penghasilan Rp.50.000.000Rp.250.000.000, sebanyak 1 orang memiliki penghasilan Rp.250.000.000-Rp.500.000.000 dan 13 orang memiliki penghasilan sebanyak $>$ Rp.500.000.000.

Analisis statistik deskriptif digunakan untuk memberikan gambaran suatu data. Jumlah data dalam penelitian ini menunjukkan sebesar 45 data. Variabel kepatuhan wajib pajak (Y) mempunyai nilai minimum 20 dan nilai maksimum 25. Rata-rata kepatuhan wajib pajak adalah sebesar 21.93 dengan nilai standar deviasi sebesar 2.310. Variabel Tax Amnesty (X1) mempunyai nilai minimum 20 dan maksimum 25. Rata-rata tax amnesty adalah sebesar 21.69 dengan nilai standar deviasi sebesar 2.193. Variabel Pengetahuan Perpajakan mempunyai nilai minimum 21 dan maksimum 30. Rata-rata pengetahuan perpajakan adalah sebesar 26.02 dengan nilai standar deviasi sebesar 2.896. Variabel pelayanan fiskus (X3) mempunyai nilai minimum 17 dan maksimum 25. Rata-rata pelayanan fiskus adalah sebesar 21.47 dengan standar deviasi sebesar 1.700 .

Variabel sanksi perpajakan (X4) mempunyai nilai minimum 16 dan maksimum 25 . Rata-rata sanksi perpajakan adalah sebesar 20.51 dengan standar deviasi sebesar 2.096. Berdasarkan tabel 2 di atas, nilai standar deviasi seluruh variabel tax amnesty, Pengetahuan Perpajakan, Pelayanan Fiskus, Sanksi Perpajakan dan Kepatuhan Wajib Pajak lebih kecil dibandingkan nilai rata-ratanya. Ini mengandung arti bahwa variasi data variabelvariabel dalam penelitian adalah rendah dan data-data bersifat homogen sehingga baik untuk mewakili populasi.

Uji validitas dilakukan untuk memeriksa validitas dari pernyataan pada kuesioner, apakah pernyataan tersebut mampu atau tidak mampu mengungkapkan sesuatu yang diukur kuesioner tersebut. Teknik yang digunakan yaitu teknik pearson correlation, dan dihitung dengan bantuan program SPSS versi 21. Pengujian ini dilakukan dengan membandingkan $r$ hitung (table corrected item-total correlation) dengan $r$ table (Tabel product moment dengan signifikan 0,05 atau 5\%). Kevalidan data dilihat jika $r$ hitung $\geq r$ tabel, maka instrumen pernyataan dinyatakan valid (Ghozali, 2011).

Uji validitas terhadap masing - masing variabel menunjukkan bahwa semua butir instrumen pernyataan dari setiap variabel pemahaman tentang tax amnesty, pengetahuan perpajakan, pelayanan fiskus, sanksi perpajakan dan kepatuhan wajib pajak dinyatakan valid, karena nilai $r$ hitung lebih besar dari $r$ tabel, dimana $r$ tabel sebesar 0,294. Sehingga semua butir instrumen pernyataan untuk setiap variabel dapat digunakan dalam penelitian ini. 
Uji reliabilitas dilakukan untuk mengetahui tingkat konsistensi terhadap instrumentinstrumen yang diukur. Reliabilitas merupakan syarat untuk tercapainya validitas suatu kuesioner dengan tujuan tertentu. Pada penelitian ini pengukuran dilakukan dengan analisis reliabilitas menggunakan alat uji Cronbach Alpha. Untuk uji Cronbach Alpha dilakukan pengukuran dengan mengkorelasikan satu item pernyataan dengan item pernyataan lain untuk setiap variabel dengan nilai cronbach's alpha $\geq$ 0,60 bisa dinyatakan reliabel.

Uji Reliabilitas terhadap masing - masing variabel menunjukkan reliabel.

Uji asumsi klasik dilakukan untuk menguji ketepatan dalam estimasi, konsistensi, dan ketidakbiasan dari model regresi yang diajukan dalam penelitian.

Uji normalitas bertujuan untuk menguji apakah model regresi, variabel pengganggu atau residual memiliki distribusi normal. Untuk menguji apakah data terdistribusi normal atau tidak dapat dilakukan dengan analisis grafik dan uji statistik (Ghozali \& Chariri, 2016). Analisis grafik merupakan cara yang mudah untuk melihat penyebaran dua (titik) pada sumbu diagonal dari grafik normal Probability plot, Penelitian ini melakukan uji normalitas dengan normal P-Plot terlihat hasil uji normalitas menggunakan P-Plot menunjukkan bahwa seluruh variabel dalam penelitian ini memiliki distribusi data yang normal.

Uji multikolineritas bertujuan untuk menguji apakah model regresi ditemukan adanya korelasi antara variabel bebas (independen). Model regresi yang baik seharusnya tidak terjadi korelasi antara variabel independen. Jika variabel independen saling berkorelasi maka variabelvariabel ini tidak ortogonal. Variabel ortogonal adalah variabel independen yang nilai korelasi antar sesama variabel independen sama dengan nol (Ghozali \& Chariri, 2016). Multikolinieritas dapat dilihat dengan Variance Inflation Factor (VIF), bila nilai VIF < 10 dan nilai tolerance > 0,10 maka tidak terdapat gejala multikolinieritas. Hasil perhitungan menunjukkan semua variabel bebas memiliki nilai tolerance lebih 0,10. Hasil perhitungan nilai Variance Inflation Factor (VIF) juga menunjukan semua variabel bebas memiliki nilai VIF $<10$. Jadi dapat disimpulkan bahwa tidak ada multikolinearitas antar variabel bebas dalam model regresi.

Uji heteroskedastisitas bertujuan untuk menguji apakah dalam model regresi terjadi ketidaksamaan variance dari residual suatu pengamatan ke pengamatan lain.

Deteksi ada atau tidaknya heteroskedastisitas dilakukan dengan melihat ada tidaknya pola tertentu pada grafik scatterplot antara SRESID dan ZPRED dimana sumbu $\mathrm{Y}$ adalah $\mathrm{Y}$ yang telah diprediksi, dan sumbu $X$ adalah residual ( $Y$ prediksi $\mathrm{Y}$ sesungguhnya) yang telah distudentize.

Hasil pengujian heteroskedastisitas dengan uji scatterplot terlihat bahwa titik-titik menyebar secara acak serta tersebar baik di atas maupun di bawah angka 0 pada sumbu Y. Hal ini dapat disimpulkan bahwa tidak terjadi masalah heterokedastisitas pada model regresi.

Berdasarkan hasil berbagai uji yang telah dilakukan sebelumnya, data yang diperoleh dalam penelitian ini layak untuk digunakan dalam analisis regresi berganda. Analisis regresi berganda dilakukan untuk mengetahui pengaruh dari variabel independen terhadap variabel dependen. Hasil dari pengujian regresi berganda dengan bantuan SPSS 21 disajikan pada tabel 6.

\subsection{Hasil Regresi Linier Berganda}

Berdasarkan uraian sebelumnya, maka persamaan regresi yang didapatkan adalah sebagai berikut:

$$
\begin{gathered}
\mathrm{Y}=0,346+0,279 \mathrm{X}_{1}+0,355 \mathrm{X}_{2}+0,023 \mathrm{X}_{3}+ \\
0,282 \mathrm{X}_{4}+\mathrm{e}
\end{gathered}
$$

Keterangan:

$\mathrm{Y} \quad=$ Kepatuhan Wajib Pajak

$\alpha=$ Konstanta

$\beta 1 \beta 2 \beta 3 \beta 4=$ Koefisien regresi

$\mathrm{X}_{1} \quad=$ Tax Amnesty

$\mathrm{X}_{2} \quad=$ Pengetahuan Perpajakan

$\mathrm{X}_{3} \quad=$ Pelayanan Fiskus

$\mathrm{X}_{4}=$ Sanksi Perpajakan

$\mathrm{e}=$ error 
Persamaan regresi linier berganda di atas dapat diartikan bahwa: nilai konstanta bernilai positif sebesar 0,346. Hal ini berarti apabila tax amnesty, pengetahuan perpajakan, pelayanan fiskus dan sanksi perpajakan diasumsikan sama dengan nol, maka nilai kepatuhan wajib pajak secara konstan akan bernilai sebesar 0,346.

Nilai koefisien regresi variabel tax amnesty bernilai positif yaitu sebesar 0,279 . Arah positif menunjukkan perubahan kepatuhan wajib pajak searah dengan perubahan tax amnesty. Hal ini berarti apabila nilai tax amensty meningkat sebanyak satu satuan maka akan meningkatkan nilai kepatuhan wajib pajak sebesar 0,279 satuan.

Nilai koefisien regresi variabel pengetahuan perpajakan bernilai positif yaitu sebesar 0,355. Arah positif menunjukkan perubahan kepatuhan wajib pajak searah dengan perubahan pengetahuan perpajakan. Hal ini berarti apabila nilai tax amnesty meningkat sebanyak satu satuan maka akan meningkatkan nilai kepatuhan wajib pajak sebesar 0,355 satuan.

Nilai koefisien regresi variabel pelayanan fiskus bernilai positif yaitu sebesar 0,023. Arah positif menunjukkan perubahan kepatuhan wajib pajak searah dengan perubahan pelayanan fiskus. Hal ini berarti apabila nilai pelayanan fiskus meningkat sebanyak satu satuan maka akan meningkatkan nilai kepatuhan wajib pajak sebesar 0,023 satuan

Nilai koefisien regresi variabel sanksi perpajakan bernilai positif yaitu sebesar 0,282. Arah positif menunjukkan perubahan kepatuhan wajib pajak searah dengan perubahan sanksi perpajakan. Hal ini berarti apabila nilai sanksi perpajakan meningkat sebanyak satu satuan maka akan meningkatkan nilai kepatuhan wajib pajak sebesar 0,282 satuan.

Uji $F$ seringkali juga dinamakan dengan analysis of variance. Pengujian ini dimaksudkan untuk mengetahui apakah variabel-variabel penjelas yang digunakan dalam model, secara bersama-sama mempunyai pengaruh atau tidak terhadap variabel yang ingin dijelaskan dengan menggunakan uji $\mathrm{F}$ test. Pengujian ini dilakukan untuk menguji pengaruh tax amensty, pengetahuan perpajakan, pelayanan fiskus dan sanksi perpajakan terhadap kepatuhan wajib pajak secara bersama-sama.

Dari hasil perhitungan uji $\mathrm{F}$ menunjukkan bahwa nilai $F_{\text {hitung }}$ sebesar 8,928 lebih besar dari $\mathrm{F}_{\text {tabel }}$ sebesar 2,59 (Ftabel $=\mathrm{k} ; \mathrm{n}-\mathrm{k}=4 ; 45-4=$ $4 ; 41, \alpha=5 \%$ ) dengan angka signifikansi 0,000 $<0,05(\alpha=5 \%)$. Hal ini berarti bahwa model penelitian adalah fit atau dengan kata lain ada pengaruh yang signifikan antara tax amnesty, pengetahuan perpajakan, pelayanan fiskus dan sanksi perpajakan terhadap kepatuhan wajib pajak.

Uji-t dilakukan untuk menguji pengaruh secara parsial antara variabel independen dengan variabel dependen dengan asumsi variabel lain adalah konstan. Pada penelitian ini taraf signifikansinya adalah $5 \%$. Hasil pengujian menunjukan bahwa tax amnesty memperoleh nilai $\mathrm{t}$ sebesar 2,086. Tingkat signifikansi menunjukkan 0,043 yang lebih besar dari taraf signifikansi $5 \% \quad(0,043<0,05)$. Hal ini berarti menolak Ha dan dapat disimpulkan bahwa tax amnesty berpengaruh terhadap kepatuhan wajib pajak. Dengan kata lain hipotesis kedua yang menyatakan "tax amnesty berpengaruh terhadap kepatuhan wajib pajak" diterima.

Hasil pengujian juga menunjukan bahwa pengetahuan perpajakan memperoleh nilai $t$ sebesar 3,519. Tingkat signifikansi menunjukkan 0,001 yang lebih kecil dari taraf signifikansi 5\% $(0,001<0,05)$. Hal ini berarti menerima Ha dan dapat disimpulkan bahwa pengetahuan perpajakan berpengaruh terhadap kepatuhan wajib pajak. Dengan kata lain hipotesis ketiga yang menyatakan "pengetahuan perpajakan berpengaruh terhadap kepatuhan wajib pajak"

\section{diterima.}

Selanjutnya hasil pengujian menunjukan bahwa pelayanan fiskus memperoleh nilai $\mathrm{t}$ sebesar 0,138. Tingkat signifikansi menunjukkan 0,891 yang lebih besar dari taraf signifikansi 5\% $(0,891>0,05)$. Hal ini berarti menolak Ha dan dapat disimpulkan bahwa pelayanan fiskus tidak berpengaruh terhadap kepatuhan wajib pajak. Dengan kata lain hipotesis keempat yang menyatakan "pelayanan fiskus berpengaruh terhadap kepatuhan wajib pajak” ditolak. 
Hasil pengujian $\mathrm{t}$ selanjutnya menunjukan bahwa sanksi perpajakan memperoleh nilai $\mathrm{t}$ sebesar 2,100. Tingkat signifikansi menunjukkan 0,042 yang lebih kecil dari taraf signifikansi $5 \%$ $(0,042<0,05)$. Hal ini berarti menerima $\mathrm{Ha}$ dan dapat disimpulkan bahwa sanksi perpajakan berpengaruh terhadap kepatuhan wajib pajak. Dengan kata lain hipotesis kelima yang menyatakan "sanksi perpajakan berpengaruh terhadap kepatuhan wajib pajak" diterima.

\subsection{Hasil Uji Determinasi}

Hasil uji adjusted $\mathrm{R}^{2}$ pada penelitian ini diperoleh nilai adjusted $\mathrm{R}^{2}$ sebesar 0,419. Hal ini menunjukkan bahwa kepatuhan wajib pajak dipengaruhi oleh tax amnesty, pengetahuan perpajakan, pelayanan fiskus dan sanksi perpajakan sebesar $41,9 \%$, sedangkan sisanya sebesar 58,1\% dipengaruhi oleh faktor lain yang tidak diteliti dalam penelitian ini.

Hasil pengujian menunjukkan bahwa secara simultan tax amnesty, pengetahuan perpajakan, pelayanan fiskus dan sanksi perpajakan berpengaruh terhadap kepatuhan wajib pajak. H1 penelitian ini diterima. Hasil penelitian ini sejalan dengan (Sari \& Fidiana, 2017) tax amnesty, pengetahuan perpajakan, dan pelayanan fiskus berpengaruh terhadap kepatuhan wajib pajak.

Hasil pengujian menunjukkan bahwa tax amnesty berpengaruh terhadap Kepatuhan Wajib pajak. H2 penelitian ini diterima. Hasil ini didukung oleh penelitian (Sari \& Fidiana, 2017) menunjukkan bahwa tax amnesty memiliki pengaruh positif terhadap kepatuhan wajib pajak. (Alfiyah \& Latifah, 2017) melakukan penelitian dengan hasil tax amnesty berpengaruh signifikan terhadap kepatuhan wajib pajak orang pribadi.

Hasil pengujian ini menunjukkan bahwa pengetahuan perpajakan berpengaruh terhadap kepatuhan wajib pajak. H3 penelitian ini diterima. Hal ini didukung oleh penelitian (Sari \& Fidiana, 2017) bahwa Pengetahuan Perpajakan memiliki pengaruh positif terhadap kepatuhan wajib pajak. Sejalan dengan penelitian (Lianty et al., 2017) bahwa Pengetahuan perpajakan berpengaruh signifikan terhadap kepatuhan wajib pajak orang pribadi di KPP Pratama Bandung Bojonagara. Hasil penelitian ini menunjukkan bahwa pelayanan fiskus tidak berpengaruh terhadap kepatuhan wajib pajak. H4 penelitian ini ditolak. Sejalan dengan penelitian (Sari \& Fidiana, 2017) menyatakan bahwa pelayanan fiskus tidak berpengaruh terhadap kepatuhan wajib pajak dan penelitian (Winerungan, 2013) yang menyatakan pelayanan fiskus tidak perpengaruh terhadap kepatuhan wajib pajak orang pribadi di KPP Pratama Manado. Untuk variabel kedua hasil penelitian menunjukkan bahwa sanksi perpajakan berpengaruh terhadap kepatuhan wajib pajak. H5 penelitian ini diterima. Sejalan dengan penelitian yang dilakukan oleh (Alfiyah \& Latifah, 2017).

\section{Kesimpulan}

Berdasarkan hasil analisis dan pembahasan yang telah dilakukan, maka dapat di tarik kesimpulan hasil analisis data dengan menggunakan metode analisis regresi linear berganda menunjukkan bahwa tax amnesty berpengaruh terhadap kepatuhan wajib pajak. Pengetahuan Perpajakan berpengaruh terhadap Kepatuhan Wajib Pajak. Pelayanan Fiskus tidak berpengaruh terhadap Kepatuhan Wajib Pajak. Sanksi Perpajakan berpengaruh terhadap Kepatuhan Wajib Pajak.

Bagi peneliti selanjutnya bisa memakai hasil penelitian ini sebagai acuan untuk mengembangkan penelitian dengan mempertimbangkan variabel-variabel lain diluar variabel yang sudah masuk dalam penelitian ini. Selain itu peneliti selanjutnya diharapkan menambah dimensi pernyataan dalam setiap variabel yang ada di dalam kuesioner penelitian.

\section{Daftar Pustaka}

Alfiyah, N., \& Latifah, S. W. (2017). Pengaruh Pelaksanaan Kebijakan Sunset Policy, Tax Amnesty , Kepatuhan Wajib Pajak. Jurnal Reviu Akuntansi Dan Keuangan, 7(2), 10811090. 
Bagiada, M., \& Darmayasa, i nyoman. (2016). Tax Amnesty upaya membangun kepatuhan sukarela.

Darussalam. (2014). Tax Amnesty Dalam Rangka Rekonsiliasi Nasional.

Devano, S., \& Rahayu, S. K. (2006). Perpajakan: Konsep, Teori dan Isu. Jakarta: Prenada Mesia Grup

Fidiana, F. (2016). Kepatuhan Pajak Dalam Perspektif Neo Ashabiyah. EKUITAS (Jurnal Ekonomi Dan Keuangan), 19(2), 260.

https://doi.org/10.24034/j25485024.y2015.v 19.i2.1768

Ghozali, I. (2011). Aplikasi Analisis Multivariate Dengan Program SPSS. Semarang: Badan Penerbit Universitas Diponegoro.

Ghozali, I., \& Chariri, A. (2016). Teori Akuntansi. Semarang: Badan Penerbit Universitas Diponegoro.

Independen, J. (2018). KPP Pratama Jambi Adakan Sosialisasi Pasfinal. Retrieved February 1, 2018, from http://www.jambiindependent.co.id/read/2017/12/15/16677/kp p-pratama-jambi-adakan-sosialisasi-pasfinal.

Kusuma, I. L., \& widyana Dewi, M. (2018). Kebijakan Tax Amnesty: Suatu Peninjauan dalam Perspektif Etika Deontologi Sebagai Bentuk Pilihan Wajib Pajak dalam Melaksanakan Kewajiban Perpajakan. Jurnal Akuntansi dan Pajak, 18(2), 204-214.

Lianty, R. A. M., Hapsari, D. W., \& Kurnia. (2017). Pengaruh Tax Amnesty , Pengetahuan Perpajakan, Dan Pelayanan Fiskus Terhadap Kepatuhan Wajib Pajak. Riset Akuntansi Kontemporer (JRAK), 9(2), 55-65.

Mahfud, Muhammad, A., \& Syukriy, A. (2017). Pengaruh Pemahaman Peraturan Perpajakan, Kesadaran Membayar Pajak, dan Kualitas Pelayanan Perpajakan terhadap Kepatuhan Wajib Pajak Badan (Studi Empiris Pada Koperasi Di Kota Banda Aceh). Jurnal Megister Akuntansi, 6(3), 1-9.
Mandagi, C., Sabijono, H., \& Tirayoh, V. (2014). Pengaruh Pemeriksaan Pajak Terhadap Tingkat Kepatuhan Wajib Pajak Badan Dalam Memenuhi Kewajiban Perpajakannya Pada KPP Pratama Manado (Vol. 2).

Mardiasmo. (2009). Akuntansi Sektor Publik. Yogyakarta: ANDI.

Mardiasmo. (2011). Perpajakan edisi revisi. Yogyakarta: ANDI.

Murti, H. W., J.sondakh, J., \& Sabijono, H. (2014). Pelayanan fiskus dan pengetahuan perpajakan terhadap kepatuhan wajib pajak orang pribadi di kota Manado. Jurnal EMBA, 2(3), 389-398.

Ngadiman, \& Huslin, D. (2015). Pengaruh sunset policy, tax amnesty dan sanksi pajak terhadap kepatuhan wajib pajak ( Studi Empiris di Kantor Pelayanan Pajak Pratama Jakarta Kembangan ). Jurnal Tarumanegara, XIX(02), 225-241.

Pramushinta, \& Siregar, B. (2011). Pengaruh Layanan Fiskus dan Pelaksanaan Sunset Policy Terhadap Kepatuhan Wajib Pajak Dalam Upaya Peningkatan Pajak. Jurnal Ekonomi Dan Bisnis, 5, 173-189.

Ragimun. (2015). Analisis implementasi pengampunan pajak (Tax Amnesty) di Indonesia.

Rahayu. (2010). Perpajakan Indonesia-Konsep dan Aspek Formal. Yogyakarta: Graha Ilmu.

Resmi. (2009). Perpajakan: Teori dan Kasus. Jakarta: Salemba Empat.

Sari, V. A. P., \& Fidiana. (2017). Pengaruh tax amnesty, pengetahuan perpajakan dan pelayanan fiskus terhadap kepatuhan wajib pajak Sekolah Tinggi Ilmu Ekonomi Indonesia ( STIESIA ) Surabaya. Jurnal Ilmu Dan Riset Akuntansi, 6 No 2(ISSN 2460-0585),

745-760. https://doi.org/10.1515/crelle.2011.129

Sekaran, U. (2006). Metodologi Penelitian untuk Bisnis. Jakarta: Salemba Empat. 
Siregar, Y. A., Saryadi, \& Listyorini, S. (2012). Pengaruh Pelayanan Fiskus dan Pengetahuan Perpajakan terhadap Kepatuhan Wajib Pajak (Studi Empiris terhadap Wajib Pajak di Semarang Tengah ). Julnal Ilmu Administrasi Bisnis, 1-9.

Suyanto, Intansari, P. P. L. A., \& Endahjati, S. (2016). Tax Amnesty. Jurnal Akuntansi, 4(2), 9-22. https://doi.org/ISSN: 2540-9646

Widyaningsih, A. (2011). Hukum Pajak dan Perpajakan. Bandung: Alfabeta.

Winerungan, O. L. (2013). Sosialisasi Perpajakan, Pelayanan Fiskus dan Sanksi
Perpajakan terhadap Kepatuhan WPOP di KPP Manado dan KPP Bitung. Jurnal EPerpajakan, Volume 1(No. 3), 960-970. https://doi.org/ISSN 2303-1174

Zuhdi, F. A., Topowijono, \& Azizah, D. F. (2015). Pengaruh Penerapan E-SPT dan Pengetahuan Perpajakan terhadap Kepatuhan Wajib Pajak (Studi Pada Pengusaha Kena Pajak yang terdaftar di KPP Pratama Singosari). Perpajakan (JEJAK), 7(1), 1-7. https://doi.org/10.1007/s13398-0140173-7.2 